\title{
The Analysis of the Results of Acceptability on the Translation Results in the Unedited Version and Edited Version in the Novel "After You"
}

\author{
Irma Fitriana Azti ${ }^{1}$; M. R. Nababan ${ }^{2}$; Djatmika ${ }^{3}$ \\ ${ }^{1}$ Student of Master Linguistics, Master Linguistics Department, Universitas Sebelas Maret, Surakarta, Indonesia \\ ${ }^{2}$ The Head of Department Linguistics, Master Linguistics Department, Universitas Sebelas Maret, Surakarta, Indonesia \\ ${ }^{3}$ The Head of Department Linguistics, Doctoral Linguistics Department, Universitas Sebelas Maret, Surakarta, Indonesia \\ http://dx.doi.org/10.18415/ijmmu.v6i4.980
}

\begin{abstract}
The main objective of this study is to compare the acceptability translation result from the translator and edited by the editor. It employed a descriptive-qualitative approach. Its data were obtained through content analysis, FGD, and observation, and analyzed with an interactive data analysis technique. The final findings of this research indicate the followings. First, the translation techniques used by translator and editing techniques used by the editor. Second, the rate of acceptability of the translation results from the translator and that have been edited by the editor. Third, the analysis of the acceptability of the translation results by the translator and that have been edited by the editor. Prior to its application, the translation techniques and editing techniques used by the translator and editor have a positive impact on the acceptability of the translation.
\end{abstract}

Keywords: Translation; Editing; Editing Techniques; Translation Techniques; Editor

\section{Introduction}

The translation is the act of converting the meaning of a text to another language. The language of the original text is often referred to as the 'source language' while the language, which is the translated language is the target language.

Translating is not just translating text from the source language to the target language. Good translating skills are also inseparable from the translator's skill to transfer the meaning and aesthetic elements - including, in this case, the style of language. Nida and Taber (1982: 12) state that, "Translating the consistency of reproducing in the receptor natural language equivalent of the source language message, first in terms of message and secondly in terms of style". From Nida and Taber's statement, there are two things in the translation process. The first is to produce a message commensurate with the source language, and the second is to produce a natural match in terms of style. However, the translation in terms of style is complicated. Nababan (2008: 59) states that stylistic complexity is one of the factors causing the difficulty of translation. 
In translating, a translator needs to use translation techniques. According to Molina and Albir (2002), translation techniques are 'procedures to analyze and classify how translation equivalence works'. Translation techniques have the characteristics that are 1) affect the results of the translation, 2) are classified by comparing the source text and target text, 3) affect the micro-units in the text, 4) are cursive and contextual, and 5) are functional.

The use of translation techniques will help translators determine the form and structure of words, phrases, clauses, and sentence translations. In addition, the translator will also be helped in determining the most appropriate equivalent in the target language. Thus, the comparability of translations can be applied in various lingual units. Besides, the use of translation techniques will not only produce accurate translations but are also acceptable and easy to read by the target text reader. The eighteen techniques proposed by Molina and Albir (2002) are adaptation, amplification, borrowing, calque, compensation, description, discursive creation, established equivalents, generalization, linguistic amplification, linguistic compression, literal translation, modulation, particularization, reduction, substitution, description transposition, and variation.

The assessment of the quality of translation is very relevant to be applied in four fields, namely 1) the field of published translations, 2) the field of professional translation, 3) the field of translation produced in the context of teaching courses of translation practice, and 4) the field of translation studied in the context of translation research (Nababan et al.: 2012).

Translation has become a significant and inseparable part in bridging the gap due to language barriers. For example are the role of translation in the relations of two countries with different languages, the translation of scientific books in foreign languages, and fiction books by foreign authors. In addition to scientific books by foreign authors, which are currently also incessantly flooding the world of internal bookkeeping is the entry of various types of external literary works into the world of Indonesian books. It can be seen from the many ranks of literary works by foreign writers that are currently easily found in many bookstores. Of course, books and novels have been translated, so that readers can understand the plot without experiencing language barriers.

In the process of translating a foreign language novel, there are two processes before the results of the translation are published on the market, namely, the source language manuscript is translated by a translator and then the result of the translation by the translator must be edit by the editor.

\section{Literature Review}

\subsection{Translation}

There are several definitions of translation that have been put forward by experts. The definitions are different because they are adjusted to their background and perspective on translation. These different points of view can complement each other.

Catford (1980: 20) states translation is the activity of replacing textual material in a language as the source language (SL) with equivalent textual material in the target language (TL). Catford considers translation to be aimed at merely replacing texts or forms. Meanwhile, the text of a language cannot be diverted without capturing the meaning of the message behind a particular expression, even the equivalent text can have a different meaning. As Mounin argues in Newmark (1988: 3) "... translation cannot simply reproduce, or be, the original" means that the process of translation cannot be considered merely to restate and maintain the original form solely of the original text, but many aspects that translators must consider to achieve comparability. 
To get the right meaning equivalent, a translator must have special competencies in the field of translation. However, most people assume that translating activities merely transfer the message of the source language into the target language. Such an assumption is very wrong. In every translation activity, a translator is always confronted with two texts at once, namely the source language and target language (Anam, 2014: 36).

\subsection{Translation Techniques}

The following are various translation techniques adapted from Molina and Albir:

a. Adaptation: Replacing source language culture elements with cultural elements that exist in the source language.

b. Amplification: Add details not formulated in the source language by adding information and paraphrases.

c. Borrowing: Use words or phrases from the source language in the target language.

d. Calque: literal translation techniques from foreign languages.

e. Compensation: Added information or stylistic effects in the source language in other parts of the target language because it cannot be realized in the same part in the source language.

f. Description: replace the form or term by describing the form or function of the term.

g. Discursive creation: using a temporary equivalent that can be far from the original context. This technique often appears in the translation of movie titles, books, novels.

h. Established equivalence: use familiar terms or expressions (based on dictionaries or everyday expressions).

i. Generalization: use terms that are well known and widely known to the public.

j. Linguistic amplification: add linguistic elements to the translation. This technique is often used in dubbing or interpreting.

k. Linguistic compression: done by synthesizing linguistic elements in the target language. This technique is often used in simultaneous interpreting and subtitling.

1. Literal translation: switch word by word from the source language to the target language.

m. Modulation: technique in which the translator changes the point of view, focus, or cognitive aspects that exist in the source language either lexically or structurally.

n. Particulation: use more concrete and specific terms.

o. Reduction: is compact information contained in the source language.

p. Substitution: replacing linguistic elements into paralinguistics such as intonation and cues or vice versa.

q. Transposition: techniques related to changing grammatical categories in the source language into the target language.

r. Variation: replacing linguistic or paralinguistic elements that affect linguistic variation.

\subsection{Editing}

Editing is preparing a ready-to-print or ready-to-publish text by paying attention to the systematic aspects of the presentation, content, and language regarding spelling, letters, punctuation, words, diction, phrases, terms, clauses, sentences, and discourse (Sugihastuti, 2006).

People who do editing manuscripts or essays that will be published in magazines, newspapers, books, etc. are called editors or editors.

Eneste in his book Buku Pintar Penyuntingan Naskah (1995) states that the requirements for becoming an editor are: 
1. Mastering spelling,

2. Mastering grammar,

3. Can use dictionaries,

4. Having language sensitivity,

5. Knowledgeable,

6. Thorough and patient,

7. Sensitive to racism and pornography,

8. Flexible,

9. Have the ability to write,

10. Mastering certain fields, and

11. Mastering foreign languages.

In translation novels, there are two steps to producing a published translation novel. The first step is the source language script translated by the translator and the second step is the translation result edited by the editor. Bambang Trim (2010) stated that in editing the translated text, an editor needs some preparation, such as:

1. Knowledge and mastery of the editor of the source language text.

2. Knowledge and mastery of editors on the source text topic.

3. The use of dictionaries, thesaurus, and also dictionary idioms.

4. Editor's insight into the source text topic, especially those related to trends.

According to him, in the context of editing the manuscript, there are seven aspects that are edited as indicators of the feasibility assessment of the manuscript, namely:

1. Readability and clarity

2. Consistency

3. Grammar

4. Clarity in language style

5. The accuracy of facts and data

6. Decency and negligence

7. Production savings (cost details and product specifications).

From those seven aspects, it appears that the problem of readability and linguistic text is also an important point. Manuscripts that contain a lot of language errors certainly have a low level of readability so that it can be difficult for the target reader to understand. For this reason, editors use empathy by placing themselves as target readers, while using their linguistic knowledge to help authors/translators display texts that are worth to reading. Thus, an editor works to link between the interests of authors / translators and target readers.

In addition to meeting the above requirements, there are five editing techniques that must be mastered by the editor in editing a translated manuscript, namely:

1. Desertion is to keep parts of the manuscript as it is because it is correct, accurate, or meets the publisher's reasonable requirements.

2. Improvement / adjustment, namely improving the text according to the rules of language or style of environment.

3. Changes, namely changing sentences, paragraphs, or structures in the text following the clarity and standards set by the publisher so that the text has high legibility.

4. Reduction is eliminating certain parts of the manuscript if the section is not needed or to make the page efficient or let the page slip up to multiple 8. 
5. Addition is to add parts of the manuscript that are considered necessary for inclusion or for releasing pages to multiple 8 .

\subsection{Translation Quality}

Translation is called good if it is oriented towards the reader and listener. For the target language text reader, the results of assessing the quality of the translation can be used as a benchmark whether the translator who produced the translation is trusted or not.

Nababan (2012: 44) argues that quality translation must meet three aspects, namely aspects of accuracy, acceptability, and readability. These three aspects are the parameters of translation quality that are interrelated with one another. Accuracy is an aspect used in evaluating translations to refer to whether the source and target language texts are equivalent. Then, acceptability refers to whether a translation has been expressed in accordance with the rules, norms, and culture that applies in the target language or not, both at the micro-level and at the macro-level. Meanwhile, readability is an aspect that is only associated with reading activities because every translating activity cannot be separated from reading activities. The readability aspect does not only concern the readability of the source language text but also the readability of the target language text.

In this study, the researcher will examine the analysis of the result of acceptability on translation results in unedited and edited versions in the novel "After You" by Jojo Moyes. In a previous study conducted by Cristina Dea Amantasari (2016), in her research, she analyzed the comparison of scientific term translation techniques on translations produced by translators and translation edits and their impact on the quality of the translations produced. In her study, the researcher used a science translation book for children. Cristina found that the majority of translation techniques used by translators and editors were established equivalents, naturalization borrowing, pure borrowing, literal, amplification, and reduction. Also, the majority of translation techniques have a positive impact on the quality of translations.

The results of this study are expected to provide benefits for academics and translator practitioners in carrying out the practice of translation. Besides this research is also expected to benefit the book editor.

\section{Research Methodology}

This research uses descriptive qualitative research. Descriptive method is the method used to collect and analyze data, and conclusions from the analyzed data. Creswell (1994: 171) states that "Descriptive method is collecting the qualitative data, analyzing them, and writing result". This research is also included in qualitative research. Creswell (1994: 15) states that "Qualitative research is an inquiry process of understanding based on distinct methodological traditions of inquiry that explore a social or human problem. The researcher builds a complex, holistic picture, facts words, detailed report views of informants, and conducts the study in a natural setting."

This research is a fixed case study based on the fact that researchers have made research limitations before conducting research.

Translation theory is used as an approach in this research. Translation theories used are translation techniques and translation quality. The translation theory is used to analyze data in order to find answers following predetermined research problems. Translation techniques are used to analyze 
whether the techniques used by translators and editors to translate are then related to their impact on the acceptability of the resulting translation.

\subsection{Instruments}

In this study, the data collected is the translation of words, groups of words or sentences that have changed from the translator's translation results, and the translation result from the editor's edit.

Data sources in this study are documents and informants. The document is a source of data, the original novel "After You" by Jojo Moyes, the draft novel "After You" which was translated by the translator and edited by the editor.

In this study, there are two types of data, namely primary and secondary data. Primary data in this study are the words, phrases, and sentences that have changed in the translation of the novel "After You" and the translation edited from the editor, the translation technique used by the translator and the editing technique used by the editor and the acceptability of the translation.

Meanwhile, secondary data in this study were informants consisting of evaluators. Assessors in this study will assist in determining translation and editing techniques which can then be assessed for the accuracy of the translation.

\subsection{Data Analysis Procedures}

Data collection techniques used in this study were the analysis of documents and questionnaires.

\subsubsection{Document Analysis (content analysis)}

Yin in Sutopo said that the technique of recording documents is a way to find various things according to the needs and following the objectives of his research (2006). In this study, researchers collected data that was the result of a translation by translators and edited translations by editors in the novel "After You" by Jojo Moyes. Besides, the researcher also identified the translation techniques used and found the impact of the application of these techniques on the quality of translation.

\subsubsection{FGD (Forum Group Discussion)}

FGDs are used to dig up data about the quality of translation in-depth to get stability. This discussion is flexible and open, does not have a strict structure, is not in a formal atmosphere, and can be done repeatedly on the same informant, (Sutopo, 2006). As mentioned above, the results of this FGD were the determinants of the data collected using a questionnaire technique. The FGD was conducted after the questionnaire was submitted and then discussed together.

The questionnaire is a list of questions for data collection in a study. This data collection technique can be done verbally or in writing, but the form is more often used (Sutopo, 2006). The questionnaire technique is carried out for information about the quality of translation, namely, closed and open questions. Closed questions relate to research on acceptability. Informants are asked to provide an assessment of the quality of translations based on the rating scale and indicators provided by the researcher. The determination of the scale or score used to assess the level of accuracy, and acceptance refers to the translation quality assessment instrument formulated by Nababan et al., (2012). 
Data analysis techniques in this study use Spradley's theory of domain analysis, taxonomy, and compatibility. Domain analysis is performed to sort between data and not data.

If domain analysis provides broad and general results, a taxonomic analysis is carried out to deepen the collection of data, namely by classifying the data according to their categories. After that, a compounding analysis is carried out to connect the relationship between data classifications and the quality of the acceptance of the translation. At this stage, the level of acceptance is related to the translation technique used.

\section{Findings}

\subsection{Translation Techniques}

In the translation novel translated by the translator, there are 13 translation techniques used by the translator, namely Established Equivalence, Discursive Creation, Literal, Modulation, Amplification, Generalization, Deletion,Transposition, Borrowing, Variation, Reduction, Adaptation, and Compensation. The application of these techniques has different occurrence frequencies. The details can be seen in the following table:

Table: 1 Translation Techniques Table

\begin{tabular}{|l|l|l|}
\hline No & Translation Techniques & Frequency \\
\hline 1 & Established Equivalence & 176 \\
\hline 2 & Modulation & 12 \\
\hline 3 & Amplification & 21 \\
\hline 4 & Discursive Creation & 23 \\
\hline 5 & Literal & 16 \\
\hline 6 & Borrowing & 9 \\
\hline 7 & Generalization & 2 \\
\hline 8 & Variation & 16 \\
\hline 9 & Transposition & 3 \\
\hline 10 & Compensation & 1 \\
\hline 11 & Deletion & 1 \\
\hline 12 & Reduction & 1 \\
\hline 13 & Adaptation & 1 \\
\hline Total & & 282 \\
\hline
\end{tabular}

\subsection{Editing Techniques}

In the translation results of the translator, out of 282 data found five editing techniques used by the editor, namely Desertion, Improvements/adjustments, Change, Reduction, and Addition. Details of the frequency of occurrence of these techniques can be seen in the following table: 
Table 2: Editing Techniques Table

\begin{tabular}{|l|l|l|}
\hline No & Editing Techniques & Frequency \\
\hline 1 & Desertion & 9 \\
\hline 2 & Improvements/adjustments & 21 \\
\hline 3 & Change & 142 \\
\hline 4 & Reduction & 102 \\
\hline 5 & Addition & 8 \\
\hline \multicolumn{2}{|l|}{ Total } & 282 \\
\hline
\end{tabular}

\section{Discussion}

The quality of translation must meet three aspects, namely aspects of accuracy, acceptability, and readability aspects (Nababan et al.: 2012).

In this study, researchers only examined aspects of acceptance. From the analysis of the translation data above, the result of the translation done by the translator is acceptable, which has a score of 2.88 out of 3 . While the results of the translation of the translator that has been edit by the editor have decreased the score to 2.83 . For more details can be seen in the table below:

Table 3: Table of the acceptability of the translator

\begin{tabular}{|l|l|l|l|}
\hline No & The Acceptability & Frequency & Percentage \\
\hline 1 & Acceptable & 252 & $89,36 \%$ \\
\hline 2 & Less Acceptable & 27 & $9,57 \%$ \\
\hline 3 & Inacceptable & 3 & $1,06 \%$ \\
\hline \multicolumn{2}{|l|}{ Total } & 282 & $100 \%$ \\
\hline
\end{tabular}

The average is 2,88

Table 4: Table of the acceptability of the editor

\begin{tabular}{|l|l|l|l|}
\hline No & The Acceptability & Frequency & Percentage \\
\hline 1 & Acceptable & 254 & $90,1 \%$ \\
\hline 2 & Less Acceptable & 7 & $2,48 \%$ \\
\hline 3 & Inacceptable & 21 & $7,45 \%$ \\
\hline \multicolumn{2}{|l|}{ Total } & 282 & $100 \%$ \\
\hline
\end{tabular}

The average is 2,83

Example from the data :

Data no: 007

SL: But he's a big guy and it's fifteen minutes till closing time and, according to company guidelines, 
TL1 ${ }^{1}$ : Tetapi dia bertubuh besar, kami baru akan tutup lima belas menit lagi, dan menurut panduan perusahaan,

TL2 2: Tetapi dia bertubuh besar, kami baru akan tutup lima belas menit lagi, dan menurut pandщan peraturan perusahaan,

In the example above we can see that the translator translates the word guidelines into guidelines, while the editor edits them into rules. In this case, the translator uses the established equivalence translation technique, while the editor uses the editing changes technique. Also, the difference does not affect the acceptance of the translation, because each has a score of 3, which means acceptable.

Data no 014

SL: I note everything in the ledger, check the pumps, jot down what we need to reorder.

TL1: Aku mencatat semuanya di buku pengeluaran, memeriksa pompa-pompa, menuliskan apa saja yang harus kami pesan lagi.

TL2: Aku mencatat semuanya di buku pengeluaran, memeriksa pompa-pompa, menuliskan apa saja yang harus kami pesan lagi.

In the example above, the translator uses the established equivalence translation technique, while the editor uses the removal editing technique. Moreover, the difference has an impact on the acceptability of the translation, which was initially accepted to be less acceptable.

Data no 017

SL: "Hello? Anyone in here?"

TL1: "Halo? Ada orang di sana?"

TL2: "Halo? Ada orang di sana dalam sini?

In the example above, the translator uses the discursive creation translation technique, while the editor uses the editing technique. And that difference greatly affects the acceptability of translations, which were initially unacceptable, becoming acceptable.

\section{Conclusion}

From the study above, it appears that the dominant translation techniques used by translators are established equivalent, discursive creation, amplification, literal, and variation. Besides, these techniques have a positive impact on the acceptability of the overall translation, as evidenced by a reasonably high score based on the weighting application, which is 2.88 . It means that the translator has applied the technique well, even though the results are not perfect. Then the dominant editing techniques used by the editor are change and reduction. The editing techniques used by editors have a positive impact on the acceptability of the overall translation with a score of 2.83 .

It can be concluded that the acceptability of the translation resulting from a translator is better than the editor's edit, this is evidenced by the increase in the original score of 2.88 to 2.83 . But the reduction has little impact and cannot be used as a reference whether the final quality of the translation is good or not. Because we also have to research about the other quality of translations, such as accuracy and legibility.

\footnotetext{
1 TL1: Target Language from translator

${ }^{2}$ TL2: Target Language tah have been edited by editor
} 


\section{References}

Albir, A.H and Molina, L. 2002. Translation Technique Revisited: A Dynamic and Functionalist Approach. Meta, Vol. XLVII, No. 4.

Amantasari, Cristina Dea. 2016. Analisis Perbandingan Teknik Penerjemahan Istilah Ilmiah pada Terjemahan yang Dihasilkan Oleh Penerjemah dan Suntingan Terjemahan pada Buku Terjemahan Sains Untuk Anak Book of Life Seri Tumbuhan Serta Dampaknya Terhadap Kualitas Terjemahan. Surakarta: Universitas Sebelas Maret Surakarta.

Catford, J. C. 1965. A Linguistic Theory of Translation. London: Oxford University Press.

Eneste, Pamusuk. 1995. Buku Pintar Penyuntingan Naskah. Jakarta: Obor. 2005. Buku Pintar Penyuntingan Naskah Edisi Kedua. Jakarta:

Gramedia Pustaka Utama.

J. Moleong, Lexy. 2000. Metode Penelitian Kualitatif [Qualitative Research Method]. Bandung: Remaja Rosdakarya.

Moyes, Jojo. 2016. After You. New York: Penguin Books.

Nababan, MR. 2008. Teori Menerjemahkan Bahasa Inggris [English Translation Theories]. Yogyakarta : Pustaka Pelajar.

Nababan, Rudolf, dkk. 2012. Pengembangan Model Penilaian Kualitas Terjemahan [Development of Translation Quality Assessment Models]. Surakarta: Universitas Sebelas Maret Surakarta.

Newmark, P.1988. Approaches to Translation. New York: Pergamon Press.

Nida \& Taber. (1982). The theory and practice of translation. Leiden: E.J.Brill.

Sugihastuti. 2006. Editor Bahasa. Yogyakarta: Pustaka Pelajar.

Spradley.P. James. 1997. Metode Etnografi. Yogyakarta:Tiara Wacana.

Sutopo, Anam. 2014. Model penelitian Terjemahan Karya Sastra. Surakarta: Universitas Muhammadiyah Surakarta.

Trimansyah, Bambang. (2010). Editing Karya Terjemahan [Editing Translation Works], Bandung.

\section{Copyrights}

Copyright for this article is retained by the author(s), with first publication rights granted to the journal. This is an open-access article distributed under the terms and conditions of the Creative Commons Attribution license (http://creativecommons.org/licenses/by/4.0/). 